bahasa \& sastra, Vol. 14, No.2, Oktober 2014

\title{
THE UNDERLYING PRINCIPLES OF SUSILO BAMBANG YUDHOYONO`S THOUGHT PATTERNS IN HIS ENGLISH SPEECH TEXTS
}

\author{
Sulistyaningsih \\ STKIP PGRI Sidoarjo \\ Address: Perum Wisma Delta 13, Sekardangan, Sidoarjo 61215. \\ E-mail: sulistya.ningsih67@yahoo.com.
}

\begin{abstract}
Abstrak
Prinsip-prinsip yang mendasari pola pikir SBY yang tampak pada Teks Pidato bahasa Inggrisnya diteliti, karena ada tanggapan dari sebagian masyarakat memuji bahwa SBY adalah presiden yang baik, tetapi yang lain mengklaim dan mengkritik bahwa dia lambat ( Djalal 200:halaman depan). Judul ini sejauh ini belum pernah diteliti. Tujuan dari penelitian ini untuk mengetahui : prinsip-prinsip yang mendasari pola pikir SBY dalam pidato teks bahasa Inggris-nya dihubungkan dengan filsafat Jawa. Penelitian ini bersifat kualitatif . Data dipilih dari Teks pidato SBY dianalisis dengan teori semantik dan pragmastylistic kemudian dihubungkan dengan filsafat Jawa. Hasil temuannya adalah: pertama Memayu Hayuning Bawana, Ambrasta dur Hangkara artinya mencapai keamanan, kedamaian, kebahagiaan dan kesejahteraan dunia dan isinya. Kedua, rukun agawe santosa crah agawe Bubrah artinya selalu membangun kondisi harmoni untuk perdamaian dunia, dan menghindari konflik; karena konflik dapat merugikan kedua belah pihak. Ketiga, tepa selira artinya menjaga perasaan tidak menyinggung orang lain, toleransi. Keempat adalah ana rembug becik dirembug artinya melalui negosiasi dapat menghindari konflik dan mencapai kerjasama, keamanan, perdamaian dan kemakmuran. Dengan kata lain diartikan untuk mencapai perdamaian dunia dapat melalui diskusi tanpa perang atau dengan soft power.
\end{abstract}

Kata-kata kunci: SBY, pola pikir yang mendasari, teks pidato

\begin{abstract}
The underlying principles of thought patterns as shown in SBY's English Speeches Texts are made because there are different responses from the public, a part of public praise that $S B Y$ is a good president, and others claim and criticize him that he is slow (Djalal, 2007: forward page). This title so far has not been investigated. This research was aimed at finding out: the underlying principles of SBY's thought patterns in his English Speech Texts related to Javanese philosophy. This research is qualitative. The data selected from SBY's speech Texts were analyzed using semantic and pragmastylistic theory then were related to Javanese philosophy. The findings are the underlying principles of SBY's thought patterns based on Javanese philosophy manifested in his English Speech Texts are: first is Memayu Hayuning Bawana, Ambrasta dur Hangkara means to reach safety, peace, happiness and well-being of the world and its contents, to keep the world maintained and harmony. Second, Rukun agawe santosa crah agawe bubrah means to build the condition of harmony, and avoid conflict, because conflict can be harmful to both parties. Third, tepa selira means keep thinking not to offend others or lighten the burdens of others, tolerance. Fourth is ana rembug becik dirembug means thru negotiations can avoid conflict and achieve cooperation, safety, peace and prosperity. In sum, the world peace can be reached thru discussions without war, soft powers.
\end{abstract}

Keywords: SBY, underlying thought pattern, speech texts. 


\section{INTRODUCTION}

Language is constructed from words and from the theory of grammar which fix on their order. Words are random conceptions of individual brain. For example, people agree a tree is named in English by the word 'tree' only because, the word give the impressions like the object, in this case the name 'tree' can be used on anything from an huge teakwood to the very small bonsai. All diversity of trees can be named according to its quality, although they are collectively named as particular group by the word 'tree' (Leakey, 1981:129). Language has been seen as a special human trait by Chomsky and his followers. Different peoples may speak different languages through cultural variation, but based on the words lies a similar grammatical structure. The reason is that language is the product of certain specific brain structures or functions. Language and culture shape one's identity and personality. This is the importance of culture and language to one's individual identity. As explained by Leveridge (2008), every human being is born the same way and has the same stage in life. The difference, however, is the environment in which each individual grows and the language he / she becomes accustomed. This creates a certain cultural identity and language, this person is different from another. Every community, cultural or ethnic group has its own values, beliefs and ways of life this clearly shows the importance of language, culture, and heritage in forming and shaping one's personality. Language and thought are intertwined; it has been accepted by many scholars since a few years ago. The earliest idea is from Watson, a pioneer of behaviorism (Chomsky, 1972) who conceives that thought is nothing but talking to ourselves, and that this talking to ourselves originates from speaking aloud. This view is then followed by Bloomfield (1974) who identifies that thinking is a system of movements that is reduced from actual speech to the point where they are no longer visible. Culture is part of the public reaction to the environment by perceiving the characteristics of a social group, includes knowledge, belief, art, law, morals, customs and any other capabilities and traditions acquired by members of the public. It is commonly described as identified system of shared meanings expressed through symbols of different things like rituals, stories and myths, which hold a group of people together and it is obvious that culture is identified as system of shared meanings conveyed through different symbolic forms, for instance: symbols, rituals, stories and myths, which hold a group of people together (Conrad. 1989:15). In addition, the word culture can be defined in a variety of ways. For example, Benedick (1983:50) states, culture is defined throughout persons see the world and guidance for people to response to what they perceive.

Susilo Bambang Yudhoyono, the $6^{\text {th }}$ president of Republic of Indonesia is known with an acronym as SBY. This research is trying to find the underlying principles of SBY's thought patterns as shown in his English speeches texts. As the head of state, SBY delivered speeches which were prepared in writing texts in the stream of speech orally. It is assumed that his speech has been influenced by his personality from his background as Javanese, education, overseas experience, and military experience of the army. Add, one of his experiences, he had been a speech writer of General Edi Sudradjat, Armed Forces Commander (1993).

In Indonesia, SBY has obtained variety of different responses from the public. There are those who praise him and those who criticize him. Some people claim that SBY is slow and doubter - while others praise him for being rational, prudent and moderate, so that all of his decisions are apt and well-thought-out (Djalal, 2007: Foreword page). In line with this response the writer implements this research entitled the underlying principles of the SBY's thought patterns as shown in his English speech texts. 
Speech texts or oral composition is more than the process of writing what is to be presented orally. (Malle, 2012: 83). It refers to text that is written to be delivered orally, the unique aspects of spoken language and audience interaction that are characteristic of oral presentation. To write full text for a speech to be given is not an idea unworthy of consideration. Speech text is the thought pattern of a person not a group, where the thought pattern was influenced by a person's background, education, experience, and culture. Speech is an utterance with a good arrangement delivered to the audience. Before delivered speech in front of the audience, speech composition frameworks must be done by speaker are about schematic arrangement of a good speech which consists of opening with a greeting, introduction, a few describes the contents, content or materials systematically address are purpose, goals, objectives, plans, measures, etc., closing (conclusion, hope, messages, greetings cover, etc.

There are two important functions serves organizing speeches. First, organization improves clearness of thought in an organized way. Second, organization enlarges the likelihood that the speech will be successful. Speeches are categorized into three main parts: introduction, body, and conclusion. The introduction of the speech establishes the first, crucial contact between the speaker and the audience. The introduction needs to complete three things: focus on audience's attention, establish goodwill and credibility, give a preview.

The audience requires seeing the speaker as someone attentively and sympathetically. Audiences pay attention to thought patterns that are interesting and worth listening to. The preview should end with a transition, a brief phrase or a pause to signal to the audience that the speech is moving out of the introduction and into the body. The body follows and is itself structured by a mode of organization, a logical or culturally specific pattern of thinking about ideas, events, objects, and processes. Good conclusions might refer back to the introduction, offer an analogy or metaphor that captures the main idea, or leave the audience with a question or a challenge of some type. Brief quotations can also make effective conclusions (just as they can make effective openings for introductions).

Thought pattern is a style of development of what that enables a writer to move his thinking in an orderly manner from the beginning of discourse composition to its conclusion (D'Angelo, 1980:70). In the mean time, Guinn and Marder (1987:7) states that thought pattern is the rhetorical operation which express and order the writers' ideas, feelings, and perceptions, comprises of a system of principles used in everyday life which are usually performed in speaking and writing. Two techniques for analyzing patterns of texts organization were proposed by D. Angelo (1980:79). The first technique is linier analysis. The second technique is the paradigmatic analysis. The purpose of linear analysis is to allow the investigator to follow the logical progression of ideas in written texts, to see how every sentence in written texts is related to every other sentence. This is done by following the linear or chronological order of ideas from one sentence to another and from one paragraph to another. To analyze the structure of written texts using the linear method, written texts is considered as a kind of extended paragraph in which all the sentences are related to each other by coordination and subordination. The using a system of numbering and indenting the sentences to show graphically the overall structure of the written texts, go from sentence to sentence, considering the logical progression of ideas. Paradigmatic analysis is a type of analysis in which the paradigm is placed in a formal scheme or pattern D'Angelo (1980:79). The purpose of paradigmatic analysis is to allow the investigator to abstract the underlying organizational pattern of the entire written texts. To get the underlying principles pattern, the following procedure is suggested. Once the linear analysis has been done, the written texts is reread carefully 
sentence by sentence to look for instances of repetition (word, phrase, clause, or meaning repetition that relate to the pattern under consideration. For example: in classification themes, key words, and phrases, such as types, parts, categories, classes and the like will recur with enough frequency that the pattern will be unmistakable). Finally, the sentences and phrases that relate to the pattern under consideration are abstracted and put into a paradigm. In the first stage, original wording of the text can be used. Then for the sake of revealing the underlying principle pattern more clearly the text is regularized. This can be done by paraphrasing, recasting the sentences in simple form. Van Dijk's term macro structure is term over all composition, which includes the connection of title, topic, and theme, while Van Dijk term micro structure may include paragraph and sentence levels.

Based on the background of the study, aspects of the thought patterns in the SBY's English speeches Texts are going to be investigated in this study: what are the underlying principles of SBY's thought patterns manifested in his English Speech Texts?

\section{METHOD}

This research was descriptive and qualitative in nature describing observed phenomena in the form of words, which as Strauss (1997) stated that a qualitative research approach explores the richest, depth, and complexity of phenomena. It focused on to understand and interpret the utterance meanings and subjects' intentions that underlie each statement as mentioned by Bogdan and Taylor (1975). This study used a documentary analysis that is, the research that analyses the written text or visual contents of a document (Frankel and Wallen, 1993: 399; Titscher et al., 2000: 5556). Frankel and Wallen suggest that political speeches, textbook, essays, newspapers, novels, magazines, articles, cook books, advertisements, and pictures can be analyzed in various ways (Bell, 1987: 55-57). In relation with the source of the data has already prepared, and it can be taken from President Republic Indonesia Web Site. This study was also referred to as content analysis (Ary, 1979:304), because the main source of data were documents which already existed prior to the start of the study. Content analysis departs from the basic assumptions of the social sciences that study of the process and content of communication is the foundation of social science studies. Description provided by experts from Janis (1965:20), Berelson (1952:18) until Lindzey and Aronso (1968) on the Content analysis, always featuring three conditions, namely: objectivity, systematic approach, and generalization. Content analysis is a research technique for making inferences that are replicable and valid data by considering the context (Krippendorff, 1993:15). As suggested by Holsti (1969: 42-43) qualitative content analysis could be used in the study: 1) to describe the characteristics of content, 2) to make inferences about the causes of content, and 3) to make inferences about the effect of content. This technique was adopted 1) to analyze the type(s) of thought patterns as shown in SBY's English Speech Texts. 2) to make inferences about the underlying principles of thought pattern as shown in SBY's English Speech Texts.

One type of the cultural artifacts was written discourse, which can also be interpreted as what is produced or used by society (Spreadly, 1980:5-6). It was surface manifestation of cultural knowledge of what was known by writer and how she expressed on the paper that was only surface manifestation of cultural behavior. In other words, the written discourse of texts and socio-cultural factors underlying was a surface understanding of the thought patterns of SBY's speech texts. Thought patterns and its principles underlying (cultural factors, including cultural values), therefore could not be directly observed. They could only be learned, and drawn a conclusion from the movement idea in the description and expression of the SBY's English speech texts. 
Since this study aimed at making inferences about the underlyining principles of SBY's thought pattern as shown in his written English Speech Texts, the first step taken was data source for this study by down loading English Speech Texts of Presiden Republik Indonesia Dr.H.Susilo Bambang Yudhoyono from Website of "Departmen Luar Negeri, Jl. Pejambon, Jakarta". Due to the twice governing periods of the Indonesia state from September 2004 to 2014, the SBY's English Speech Texts were taken from the period of the year 2006 to 2012, there were 20 titles of speech texts, and then, were reduced to become three titles of speech texts based on random samples, and then ideas in the paragraphs containing main points of thought patterns in the SBY's speech texts were indentified.

All main points in the paragraphs were analyzed based on semantics and pragmastylistics, identifyed the meaning of key words in each paragraph, matched with Javanese philosophy. The next step was inferring the meaning classifying the Javanese philosophy, then counting and deciding pertestages. Then, based on the $1^{\text {st }}$ grade to $5^{\text {th }}$ grade of classification identified, the underlying thought patterns were found.

\section{RESULTS AND DISCUSSION}

On the basis of the steps proposed by Miles and Huberman, in reducing the data of this research, they were selected, were reduced based on rhetorical frame work. For that, in this research was used step by selecting a) sentences containing SBY's main points of thought patterns from the texts, b) construction of study statement of SBY's English speech texts, resulted the titles of the following English speech texts.

a. Keynote Speech by DR. H. Susilo

Bambang Yudhoyono President of the Republic of Indonesia, at the Opening of International Conference on "A Building Permanent Peace in Aceh: One year After the Helsinki Accord " 15 August 2006. b. Shared Responsibility for Common Prosperity. Statement by DR. H. Susilo Bambang Yudhoyono President of the Republic of Indonesia, at the $14^{\text {th }}$ Non Alignment Movement Summit, Havana, Cuba, 15 September 2006.

c. Welcoming Remarks by Dr. H. Susilo Bambang Yudhoyono President of the Republic of Indonesia at the Indonesia Co-Co (Collaboration and Cooperation) Night. "Celebrating the Spirit of Collaboration and Cooperation", 27 January 2011, Switzerland.

In this study the movements of ideas at the macro (overall composition level) and the micro (paragraph level) of the SBY's speech texts were analyzed. The semantic and pragmastylistic aspects of the rhetorical style are identified and analyzed. Then, texts analyzes were employed to identify the cultural thought patterns manifested in the SBY'S English speech texts.

Explaining the types of thought patterns were shown in SBY's English Speech Texts; the writer proposes two techniques for analyzing patterns of texts organization. D'Angelo (1980:79, Kibrik 1977: X) the first technique is called the linier analysis. The second technique is called the paradigmatic analysis. The purpose of linear analysis is to follow the logical progression of ideas in written texts, to see how every sentence in written texts is related to every other sentence. This is done by following the linear or chronological order of ideas from one sentence to another and from one paragraph to another.

To analyze the structure of written texts using the linear method, written texts are considered as a kind of extended paragraph in which all the sentences are related to each other by coordination and subordination. To identify the movement ideas in the overall composition, the topics manifested in every paragraph in the overall composition are identified and sequenced using a system of numbering and indenting the sentences to show graphically the overall 
structure of the written texts, go from sentence to sentence, considering the logical progression of ideas.

The second, paradigmatic analysis is then a type of analysis in which the paradigm and placed in a formal scheme or pattern. The purpose of paradigmatic analysis is to abstract the underlying principals manifested in organizational pattern of the entire the SBY's English speech texts.

To get the underlying pattern, the following procedure is suggested. Once the linear analysis has been done, the written texts is reread carefully sentence by sentence to look for instances of repetition (word, phrase, clause, or meaning repetition that relate to the pattern under consideration. For example: in classification thesis statements, key words, and phrases, such as types, parts, categories, classes and the like will return with enough frequency that the pattern will be unmistakable).

Finally, the sentences and phrases that relate to the pattern under consideration are abstracted and put into a paradigm. In the first stage, original wording of the text can be used. Then for the sake of revealing the underlying pattern more clearly the text is interpreted using semantics and pragmastylistics and then is fitted to the similar meaning to Javanese philosophy. This can be done by interpretation, describtion, and explanation D'Angelo (1980:79).

In this study used investigator triangulation, where several different researchers or evaluators are used. To maintain validity and avoid personal bias, the analyst regularly set to cross check their findings and reason out agreement findings. The technical term for this process is triangulation (Miles and Huberman, 1992: 234-235). This triangulation is intended to make the data analysis, the interpretation and explanation.

To make inference relating to the underlying principles of SBY's thought patterns regarding Javanese philosophy manifested in his English Speech Texts, informal interview with experts in Javanese culture and philosophy was conducted.

The underlying principles of thought patterns relating Javanese philosophy manifested in SBY's English Speech Texts.

Thought patterns of Javanese people are always longed for the safety of welfare constitute fundamental of the Javanese philosophy on memayu hayuning bawana, ambrasta dur hangkara which is the manifestation of thinking process shown in way of life of Javanese people. This thought pattern give birth the Javanese philosophy of life which is identical with the Javanese way of life. Term way of life has similar meaning to Javanese philosophy and ideology of Java. Meaning is a matter of the role an expression plays in human social behavior. To know expression's meaning is just to know how to deploy the expression appropriately in conversational setting, as stated by William (1999:89).

The mindset of Java is also the precipitate spiritual experience followed by Javanese people. The experience is fundamental to form ideology of life. If the ideology is left out, as if there are incomplete things in Javanese life. Thought pattern is Javanese way of life of developing ideas as the way of life that must be lived well in line with the philosophy of life, is in the form of anything that could expose the channels view of the universe, a belief that is lived as a motivating value of life based more on the appreciation and practice of the rational logical system. There is aspect of relations between languages and behaviour that whole ways of talking affect whole modes of behaviour.

\section{Example of analysis of the underlying principles of thought patterns regarding Javanese philosophy manifested in SBY's English Speech Texts.}

The following SBY's English speech texts are analyzed in order to reveal the 
underlying principles of thought patterns regarding Javanese philosophy manifested in SBY's English Speech Texts. The speech text entitled Building Permanent Peace In Aceh : One Year After The Helsinki Accord.

S1\#17 For a very long time, the positions of the Indonesian Government and GAM were diametrically opposed. Both the Indonesian Government and the GAM tried to pursue dialogue: but a humanitarian pause, and a cessation of hostilities agreement, broke down. And each time the dialogue broke-down, mistrust, suspicion and animosity became stronger.

Differences of opinion are usually resolved by consultation, like in Javanese Philosophy ana Rembug becik di Rembug. In this time SBY is trying to resolve the conflict by using negotiation. In this reality, they both the Indonesian Government and the GAM tried to pursue dialogue, eventhought they were failed.

S1\#19 You see, Aceh was a very personal issue for me.

When I served as Coordinating Minister for Politics and Security in the previous Government, I spent my entire energy trying to find ways to end the conflict.

For a while, things looked promising, especially with the signing of the Cessation of Hostilities Agreement (COHA) in Geneve on December 9th 2002

S1\#20 But unfortunately that Cessation of Hostilities Agreement collapsed, despite our last minute efforts to save it in a Conference in Tokyo in mid-2003.

After the failure of the Tokyo conference, I remember thinking that we now had to embrace ourselves indefinitely for a prolonged conflict, with all its consequences.

As implied in the Javanese philosophy ana rembug becik dirembug, means there is negotiation, problem is better to be negotiated, therefore, SBY, select the COHA (Cessation of Hostilities Agreement) agreement in Geneva 9th December 2002, and Conference in Tokyo, in mid-2003 to solve problem in Aceh; although both of the peace agreements removed the self-interest for the mutual interest, and failed. For this decision, SBY did not select war.

S1\#22 But there was one particular lesson from the COHA experience that would be critical for me in future peace efforts. I came to appreciate a peace process, to be successful, always requires focused, sustained and creative efforts and determination at the highest level of leadership. Negotiators need assurances, political back-up, instant decisions, close engagement, constant guidance. Without these, they would not be able to move far in pursuing peace.

To avoid conflict between Aceh people, SBY come to appreciate peace process, to be successful, requires focused, sustained and creative efforts and determination at the highest level of leadership. In order to reach close engagement, constant guidance based on COHA experience. In Javanese philosophy Rukun agawe santosa, crah agawe bubrah means that means harmony can make strong power, as in the lives of neighbors; this philosophy of language is always trying to maintain good relationship with neighbors, since neighbors are more valuable than the relatives who live far away.

S1\#26 You see, the tsunami produced an overwhelming moral, political, economic, social imperative to end the conflict. 
I called on GAM to end the conflict and to work together with us to help the tsunami victims. To underline my seriousness, I instructed the TNI --Indonesian Military -- to stop all military offensives, to focus solely on tsunami humanitarian operations, and I instructed my officials to stop any harsh public rhetoric on GAM.

In paragraphs S1\#26-S1\#27, In this situation, SBY called on GAM to end the conflict, to work together to cover the tsunami victims, and to celebrate Aceh Peace. Paragraph S1\#26 Budi dayane manungsa ora bisa ngungkuli garise Kang Kuwasa. Human-mind can not cope with the destiny of the Almighty. These happenings is the power of Javanese philosophy Rukun agawe santosa, crah agawe bubrah that means harmony can make strong power, as in the lives of neighbors; this philosophy of language is always trying to maintain good relationship with neighbors, since neighbors are more valuable than the relatives who live far away.

S1\#28 So we began to extend the olive branch to GAM. We started this process by informally communicating with the GAM leadership abroad, particularly in Stockholm, as well as with the GAM military commanders in Aceh.

S1\#29 And so to cut a long story short, with the help of Helsinki-based Crisis Management Initiative (CMI) led by President Martti Ahtisaari, the representatives of the Indonesian Government and GAM met in Helsinki in the first round of informal talks, in January 2005.

In Javanese philosophy perang iku tanpa guna, lamun asile ora ana; Migunani yen asile ana, war is useless, if no profitable; but it is used if profitable. Ana rembug, becik dirembug, means all conflicts can be solved by negotiations, this mindset relate to the representatives of the Indonesian Government and GAM met in Helsinki in the first round of informal talks, in January 2005.

S1\#30 At this time, I was criticized by those who did not see any benefit from renewed talks with GAM. But I was more concerned about the judgment of history for missing this rare window of opportunity to resolve the conflict.

S1\#31 There was also criticism that renewing talks with GAM would dishonor those who had lost their lives in this conflict. But I argued that the purpose of this new push for peace would be precisely to prevent more avoidable casualties, both to our soldiers and police, as well as to the people of Aceh. It would be peace with honor and dignity, and it would be a peace where our principles would be protected.

S1\#32 I was also criticized for sending 3 Cabinet Ministers to meet with GAM representatives, unlike previous talks where the Government was represented only by senior officials.

I understood this concern, but I needed to send a clear signal to GAM that I meant business, that decisions would be honored, and that my negotiators would always have direct round-the-clock access to me for instant decisions and guidance.

And this, I think, became an important factor in the dynamics of the negotiations. During the Helsinki negotiations, I spent many sleepless nights, along with Vice-President Yusuf Kalla, communicating with our negotiators in Helsinki on the critical issues that were tabled.

S1\#30 - S1\#32, although there were criticisms from various parties, SBY still wanted to try to reach an agreement by peaceful means. Criticisms like this can be included in Javanese philosophy says Aja dumeh mundhak keweleh, which means do not under estimate the ability of other people, if it is proven true, then it is obtained shame only. In Javanese 
culture, to appreciate the inherent value of other people's opinions, since it is realized that not everyone has the same opinion, as in the expression of the philosophy of Javanese culture, 'seje endas, seje penggagas', which means, in different heads, there is different way of thinking (Department of Education, 1985:169, in Sedyawati, 2003:144). SBY felt confidence in doing negotiations, like Javanese philosophy is ana rembug becik dirembug (negotiation = rembug). The first round of talks between GAM and the Indonesian government held in January 2005

S1\#33 Indeed, I remember making it perfectly clear to my negotiators that our objective was NOT "to terminate the enemy", but "to terminate the conflict, and transform the enemy." I did not know how long the peace talks would last, but I told them to persevere with the talks for as long as they could. I also told them that to avoid any misunderstanding about this new peace process, I would do all I can to communicate with all our domestic players....

The objective above was NOT "to terminate the enemy", but "to terminate the conflict, because Javanese people Thought Patterns toward Rukun agawe santosa means harmony can make strong power, as in the lives of neighbors; Javanese people are always trying to maintain good relationship with neighbors, since neighbors are more valuable than the relatives who live far away.

S1\#37 And our special gratitude to President Martti Ahtisaari for his hard work and leadership in ensuring the successful outcome of the Helsinki talks. I fondly remember our very productive meeting in Jakarta in mid-2005 to discuss ways to advance the negotiations, and when I met you, I immediately knew that we had a strong and skillful advocate of peace in you. President Ahtisaari, may I kindly ask you to stand up so we can show our appreciation for your work.

SBY Showed respect attitude and special gratitude to President Martti Ahtisaari, that was the attitude shown SBY which was the privilege of Java, with lofty ideals, the culture of peace. Principles in peace, "rukun" the conditions of social balance without conflict.

S1\#39 Peace has now broken out. Yes, peace has erupted, it has flared, it has bred, multiplied and spread. And in contrast with the destructive force of the tsunami, this peace has been a very constructive and positive force. It has had a life changing impact on many Acehnese.

Peace is in contrast to the destructive force of the tsunami, peace has become a force that is constructive and positive. It has been life-changing impact on many more suitable conditions of the philosophy of Javanese: Rukun agawe santosa, crah agawe bubrah that means harmony can make strong power, as in the lives of neighbors; this philosophy of language is always trying to maintain good relationship with neighbors, since neighbors are more valuable than the relatives who live far away.

S1\#40 Today, one year after Helsinki, the hostilities are gone. The bloodshed is no more. The guns are silent. Arms have been surrendered and destroyed by international monitors. GAM members have come out of their terrain, and they are reintegrating with society with full political, economic and social rights restored. The TNI and Police have been relocated. Amnesties have been given. GAM leaders from abroad have returned to Indonesia. Former combatants are now praying in the same mosques, and some are playing football, and even watched the World Cup together. The term "brothers and sisters" are now used instead of "enemies".

Conflict is over, and the enemy has gone, the people have fun and pray. With the hope 
of harmony makes peace, fighting makes destroyed condition. This harmonious relate to the Javanese philosophy rukun agawe santosa, crah agawe Bubrah.

S1\#42 Ladies and Gentlemen,Now, to the question: What have we learned from the Aceh peace ?

S1\#43 Well, I think on a philosophical level, there is the lesson that any conflict, no matter how difficult and intricate, CAN be resolved. You just have to find the right time, the right ingredients, and the right key to unlock the problem. I believe in my heart that although every conflict is unique, and has its own dynamics and complexities, every conflict is amenable to peaceful resolution. And this was proven in Aceh.

Paragraphs S1\# 42 and S1\#43 proved that all conflicts can be resolved. The example shown by SBY that he can achieve independence of Aceh through the negotiations. In Javanese philosophy negotiation is important like ana rembug becik di rembug means all conflicts can be solved by negotiations. This effort became an example of getting success without war that harms the various parties, this is also like the expression of the Javanese philosophy that says, 'Sugih tanpa banda, sekti tanpa aji-aji, wani perang tanpa bala, menang tanpa ngasorake' that means rich without property, brave without magic spells, won battle without reinforcements, won without a defeat. It means both sides have no one injured, and both sides got benefit.

S1\# 52 To be successful, that permanent peace will have to be built on human security, political reconciliation, economic reconstruction, and social unity.

S1\#53 That permanent peace also requires the Acehnese political leadership to develop an ability to work together in Aceh's new political format. The process of trust and confidence building which finally emerged from the Helsinki talks must now be emulated and spread throughout Aceh. The people of Aceh, more than ever, desperately need to see that their leaders are able to provide them with guidance and wisdom in this critical time of transition. We must not let them down.

Paragraph S1\#52 and S1\#53: to achieve success, the President was convinced that permanent peace must be constructed in mutual aid cooperation between Indonesia and human security, political reconciliation, economic, and social culture or in Javanese Philosophy gotong royong. In daily life to preserve the lives of the Aceh people, has implications in the philosophy of 'Memayu Hayuning Bawana, Ambrasta dur Hangkara', means reaching safety, happiness, and prosperity of Living in the world, as the increase and spread, welfare, development of spirituality and holiness in the family, community, and culture.

S1\#55 I have every confidence that we will be able to attain this permanent peace. The Acehnese have now tasted the real fruits of peace. There is no way they want to return to the old days of conflict. This is the will of the people that we must listen to and follow.

S1\#57 Today, the people Aceh can hold their heads up high, for they now have a story to tell the world, a story that they can be rightfully proud of.

S1\#58 The Acehnese can tell the world they have successfully put an end to 30 years of long bloody conflict. They have also refuted and reversed the notion that Indonesia is on the verge of "Balkanization", a theory that was rather popular a few years ago.

As a result of the Aceh peace, Indonesia is more whole, more united, more solid, and more peaceful.

S1\#57 Today, the people of Aceh can hold their heads up high, I could see the eyes of the Acehnese glowing with optimism and pride for what their community has become. This explanation have meaning how happy people of Aceh after getting peace day. This can relate to the Javanese philosophy as Suro duro jaya ningrat, lebur dening pangastuti (Bangun jiwa, 
2009:187) means power over the universe will be dissolved by the praise and worship. In times of violence and rage raging, people requested more silent in prayer and attitude of soulconscious.

Paragraph S1\#58 As a result of reaching the Aceh peace, Indonesia is more united, more solid, and more peaceful, it can be said in Javanese philosophy Memayu Hayuning Bawana, Ambrasta dur Hangkara.

S1\#60 The resolutions to all these conflicts will not be easy. We shall all continue to pray for peace in these hot zones. But I do hope that the world will take notice that here at the northern tip of the island of Sumatra, the burning flames of war have been put out for good.

The world can be reminded that conflicts can have a happy ending, as the resilient people of Aceh now move on with a life of unity, dignity and progress which is rightfully theirs.

Praying for permanent peace in Aceh, because Javanese Philosophy says "Negara kang kasuwur kasinungan kanugrahaning Hyang Widi, maujud tatanan praja lan tatananbatin kang murakabi rahayuning bangsa, wadya balane kuwat lan kawulane sujud, meaning the famous state protected by God, realizing governance and inner well-being worthwhile, for the unity of the nation, having strong army and loyal people (Marwoto, 2008:90). Conflict in Aceh can have happy ending Memayu Hayuning Bawana, Ambrasta dur Hangkara

S1\#61 I do not know the answer as to who exactly won the conflict, but I do know we all have won the peace.

SBY utters 'I do not know the answer as to who exactly won the conflict, but I do know we all have won the peace' in the philosophy of Javanese is 'sing sapa temen bakal tinemu', means whoever honestly, will get succeed for Aceh peace. Who exactly won the conflict? All have won the peace. menang tanpo ngasorake, all become the winner without defeat, like keno iwake, ojo buthek banyune, means get the fish without making water dirty or getting succeed without harming anyone. All have won the peace means there are no conflicts anymore or memayu Hayuning Bawana, Ambrasta dur Hangkara achieved.

S2\#3 We are today confronted by old persistent challenges as well as by new threats to global security. Let me name a few: inter-state and intra-state conflicts, terrorism, and the proliferation of all kinds of weapons, transnational crime, poverty, pandemics, and natural disasters.

S2\#4 The only way to effectively address these problems is by strengthening multilateralism in world affairs.

When ever SBY was delivering his speech, he told about confrontation done by old persistent challenges as well as by new threats to global security, he said that the only way to effectively address these problems is by strengthening multilateralism in world affairs. His Thought Patterns in solving the case has characterized the Javanese philosophy to form gathered power of Gotong Royong or working together as multi lateral for reaching world peace, such as Memayu Hayuning Bawana, Ambrasta dur Hangkara, this philosophy has a sense of reaching salvation of the world, keeping the world and everything maintained and harmony. (See Appendix 26, page 315).

S2\#5 Our Movement can strengthen this multilateralism by reaffirming the purpose and principles of the Non-Aligned Movement as enunciated in 1961 when our Movement came to birth. We must also reaffirm our faith in the Ten Principles of Bandung-or the Bandung Spirit-articulated by the first generation of African and Asian leaders that inspired the birth of our Movement. 
To make stronger the purpose of the unity and integrity SBY ordered to reaffirm the principles of the Non-Aligned Movement reflecting patterns of thought and mind teasers of the Javanese people who are always longed for salvation of the world, keep the world and its contents maintained and harmonized relating to Memayu Hayuning Bawana, Ambrasta dur Hangkara one of the philosophy of the Javanese that means humans live in the world should pursue safety, happiness and well-being.

S2\#8 Thus, as we chart our course for the future, we do not have to reinvent the wheel. We need only to reaffirm our commitment to the principles of independence, peace, justice and equality. And we need to figure out how to operationalize these purpose and principles of our Movement to the realities and challenges of our time.

S2\#9 The most persistent of these security challenges is the conflict in the Middle East. Diplomacy must now be given a chance to succeed. The Roadmap to peace must be revived. And Palestine and Lebanon must be rebuilt.

We need only to reaffirm our commitment to the principles of independence, peace, justice and equality is closely related with Memayu Hayuning Bawana, Ambrasta dur Hangkara, this philosophy of Javanese has a sense of reaching independence, peace, justice and equality of the world, keeping the world and everything maintained, and harmony. How to handle conflict, according to Javanese is through diplomacy, it is in accordance with the philosophy of Keno iwake ning ojo buthek banyune, that means to achieve the goal of world peace without conflict with the surrounding world and without harming others. The world peace can be achieved without war, specially the peace in Palestine and Lebanon.

S2\#10 Another challenge that has burdened our predecessors and one which we must continue to address with vigor is the threat of poverty.

Neither peace nor security can be assured on the long term while 80 percent of humanity

S2\#11 controls only 20 percent of the wealth. Democracy is meaningless to the eight million human beings who will die in 2006 because they are too poor to live.

S2\#12 Among the dire consequences of not dealing with poverty is a sense of deprivation and resentment among the poor that leads to prejudice, hatred and conflict. Thus, violence can spread out all over the world.

In facing the threat of poverty, SBY pays attention based on the Javanese thought pattern or mind set (it refers to democracy is meaningless to the eight million human beings who will die in 2006 because they are too poor to live). The wealthy people are asked to implement community care for the weak. In the shapes of Mutual cooperation that is channeled through the philosophy of Gotong royong tanpa pamrih, because the Javanese community is a collective society, not individualist. Things like this mostly are shared by middle-class community to low community, a sense of initiative to help each other. For example, the rich people help together to build a house for the weak.

S2\#12 We must therefore conquer poverty before it kills our future. And the only way to conquer it is for the developed and developing world to carry out a contract of partnership that defines their respective obligations to each other, including our own partnership and cooperation.

S2\#13 That contract already exists-in the form of the outcomes of the social and economic summits that were held by the international community during the past decade and a half. We need only to affirm our commitment to that contract and find the political will to carry it out to completion.

Based on the Javanese philosophy tepa selira, which has meaning one must attempt to understand the situation by helping others, caring for others as the philosophy aja dumeh that has meaning one must concern for others, for those who have the power do not arbitrarily the weak. In line with one feature of modern society, SBY advised the developed countries to help 
developing countries growing, starting with the opening up of their markets to the products of the developing world, especially agricultural products.

Further, partnership and cooperation is in line with Gotong Royong tanpo pamrih of Javanese philosophy, by carrying out a contract of partnership between developed and developing countries that defines their respective obligations to each other, including partnership and cooperation.

S2\#15 Second, the developed countries must earnestly address the critical need of the developing world for debt relief. Many developing countries fail to fund their socioeconomic development programmes because their budgets are bled dry by debt servicing debt trap that in many cases are not the fault of the borrowing countries. The developed countries must be bolder and more innovative in extending debt relief. Emphasis should be given to debt for environment swaps because they bring about the double benefit of debt relief and environmental sustainability.

This suggestion is related to Javanese philosophy Gotong royong lan sepi ing pamrih, rame ing gawe' means every person should help others without expecting praise or reward of any kind. This expression as the background view that humans are part of another human being because each individual is inseparable from every other individual in his life.

S2\#18 Partnership is a two way street. On the part of the developed countries this is the time for compensating for the resources they extracted from the world that they once colonized. This can be done by assisting the developing countries and building partnerships with them. Fairness and justice demands that the history of nations and the suffering they underwent must be taken into account. The developing countries must take an active part in writing the new rules of the game in a globalized world.

The main idea of the above paragraph (S2\#18) means that the developed countries and the developing countries must work together to construct building partnership within them. This context is inline with the Javanese philosophy 'Rukun agawe santosa', it means harmony can make strong power, as in the lives of neighbors, Javanese people are always trying to maintain good relationship with neighbors, since neighbors are more valuable than the relatives who live far away.

The developing countries, in turn, must fulfill a set of responsibilities that match those of their developed partners.

The above main idea (S2\#19) is closely approached to 'Rukun agawe santosa the Javanese Culture philosophy which means people must be willing to accept the obligations and responsibilities. They must be sensitive to do everything that must be accounted for accountability, for the purpose of developed countries, safe, tranquil, and prosperous.

S2\#20 The first obligation of a developing country is to practice good governance. Public and corporate officials must be accountable in a regime of transparency. This means that a determined battle must be waged against corruption. This is not an easy thing to do but it must be done.

Philosophy of Javanese to get memayu hayuning bawono, is closely related with SBY's utterance in Javanese culture, person must have a sense of tolerance: creativity, taste, and 
intention because in Javanese culture, people always pay attention to practice good governance, Public and corporate officials must be accountable in a regime of transparency, corruption must be eliminated in order to keep maintained peace and harmony associated with Education, Health, human recourses, surrounding, and nature condition.

S2\#23 Fourth and finally: we must ensure the sustainability of our environment. We must use our resources with wisdom so that these are not depleted in a way that will rob our future generations of their birthright.

This suggestion is consistent with the philosophy of human relationships with nature, Memayu Hayuning Bawana, Ambrasta dur Hangkara, this philosophy has meaning every man should take care of the surrounding environment and its contents in order to be sustained and harmonious. Every man should establish, maintain, and preserve the environment for the prosperity of the world and for future generations.

S2\#24 If both the developed and developing countries live up to these obligations, our developing economies will be sustained and empowered. We will attain our Millennium Development Goals.

If both developed and developing countries have fulfilled these obligations, our economy will grow, will be maintained and reinforced. The meaning of this phrases are similar in the philosophy of Java "jer basuki mawa bea", i.e. to achieve success, efforts are needed, sometimes need sacrifice. Sacrifice in philosophy is not always in the form of money but it may be a sacrifice of time, feelings, energy and others. We will attain our Millennium Development Goals or Mewayu, hayuning bawono.

S2\#25 Having done that, we will become stronger partners of the developed world.

After applying the philosophy Gotong Royong, or cooperation between developed countries and developing countries, a strong unity of the State Developed countries is achieved it is relate to the Javanese philosophy of Memawayu hayuning bawono, achievingour Millennium Development goal of the world.

S2\#26 In such a prosperous world, it is easier to keep the guns silent. Peace has the best of chances. And democracy has a wider space to march on. These are the ultimate goals of our Movement. And the cherished dreams of the human race.

From a prosperous and peaceful country is easier to maintain harmony and avoid conflict. As revealed in Javanese philosophy, Rukun agawe Santosa, crah agawe Bubra means harmonious guide to a prosperous, broken guide to failure or a better guide in harmony and cooperation will lead to ultimate goal of world peace, on the other hand conflict countries will lead the valuable expectation to be destroy.

\#1 Excellencies, Friends of Indonesia, My Friends. Opening with greeting

Javanese people practice tepa slira in their interaction with another one. Because principle tepa slira is to extent the politeness, might need to respect, avoid conflict, to smooth relationship. The other principle which is believed to contribute closeness is andap asor in order to avoid violation, humiliation, and conflict. 
bahasa \& sastra, Vol. 14, No.2, Oktober 2014

S3\#3 I am very pleased to welcome all of you to Indonesia Co-Co Night. I actually like the sound of it - Co-Co Night - it sounds very tropical, very inviting, and very delicious.

S3\#4 Well, unfortunately, Co-Co is not food. Co-Co is short for "collaboration and cooperation". These simple words define the spirit of our participation here at the World Economic Forum.

S3\#3 Politeness style doing andap asor to respect audiences, for building closeness and avoid conflict. Paragraph S3\#4 Co-Co is short for "Collaboration and cooperation" Symbolizes cooperation that common practiced by the Javanese people. In Javanese philosophy known as "Gotong royong" or Mutual Aid that can build power and unity. It also means working together as multi lateral for reaching world peace because the Javanese community is a collective society, not Individualist.

S3\#11 How many economies grew 4,5\% at the abyss of the recent global financial crisis ?

S3\#12 How many communities successfully rebuilt itself after being dealt with a devastating tsunami and earthquakes?

S3\#13 How many democracies effortlessly find confluence with Islam and modernity ?

S3\#14 And how many countries bounce back resiliently no matter how hard they are being hit by misfortunes and tragedy?

Paragraph S3\#11, for economies grew 4,5\% at the abyss of the recent global financial crisis Dol-tinuku: madhep ngalor sugih, madhep ngidul sugih, means although people want to become rich, wealth for the Javanese is not just money, but the wealth of a happiness and social relations, to multiply brother, not to gain fortune. Paragraph S3\#12 Ana rembug becik dirembug there is negotiation, any conflict is better to be negotiated. Paragraph S3\#13, country that quickly builds a democratic state in just a few years, can get transition from political turmoil to stable democracy in just a few years, it means the country have reached Memayu Hayuning Bawana, Ambrasta dur Hangkara, meaning is able to effort Memayu Hayuning Bawana, Ambrasta dur Hangkara to seek Safety, Happiness, and Prosperity of Life in the World. S3\#14 Rawe-rawe rantas, malang-malang putung means everything that blocked intents and purposes should be removed.

S3\#16 I will spare you the complex statistical details about Indonesia, but I do want to share the result of one independent poll taken 2 years ago in Indonesia. The poll found that $85 \%$ of Indonesians believe that their country is on the right track. 85 per cent, only after 10 years of democratic transition - that is a remarkable figure by any standard.

S3\#17 My second task is to announce the beginning of the process to set up the World Economic Forum's third country network of the Disaster Resource Partnership in Indonesia. This means when natural disasters happen again, as they are bound to, there can be quick response and recovery efforts from a tri-sector collaboration and cooperation between governments, the humanitarian workers and the private sector. I understand that the partnership will also work on prevention efforts.

S3\#18 I would like to give appreciation to the global Engineering and Construction Sector for this initiative and look forward to the upcoming dialog and process to establish this network in Indonesia.

Paragraph S3\#16-18, to set up the World Economic Forum's third country network of the Disaster Resource Partnership in Indonesia. This idea relate to the philosophy of Javanese Gotong Royong.

Look forward to the upcoming dialog and process to establish this network in 
Indonesia is relate to Javanese philosophy "ono rembug becik dirembug" means to reach the goal, it is good to make dialog for achieving agreement.

My third and final task tonight is to honor you, and to thank you for your friendship for

S3\#19 Indonesia. For those who have known us for a long time, I am sure you will be pleasantly surprised at how much Indonesia has changed for the better in recent years. For those who are newly acquainted to us, I hope you will be our life long friend.

S3\#20 And most importantly, no matter how long you have known us, I hope that you can feel our humble pride for our country, and feel our optimism about what we have become and what the future holds.

In paragraph S3\#19,20 to honor you, and to thank you for your friendship for Indonesia is relate to Javanese philosophy "Tepa slira" is the relationship between human beings that act mutual respect, and demonstrate sympathy with gratitude, and make eternal human relations. Text in paragraph S3\#20 is in contrast from nature "Ojo dumeh" or Ojo sok is looking down on other people.

S3\#21 Finally, and most importantly, have a good time at our Indonesia Co-Co night.

S3\#22 Enjoy our Indonesian music, dance and cuisine.

S3\#23 Tonight we are only giving you bite size tasting portions. Because we want you to come and taste the real thing in Indonesia. Please join us at the World Economic Forum - East Asia in Jakarta on June 12-13, 2011.

S3\#24 Enjoy the evening and thank you once again for joining us tonight

S3\#25 Thank you.

Paragraph S3\#21-S3\#25 was just purposing and persuade to enjoy all entertainments prepared, in order to respect the visitors. The effort of making harmonious atmosphere, SBY was offering foods, enjoying Indonesian music, dance, and cuisine that all of them for the purpose of tepa selira.

The Results of Analysis SBY's Speech Texts Based on Javanese Phylosophy

\begin{tabular}{|l|l|c|c|}
\hline S1\#60 & Memayu Hayuning Bawana, Ambrasta dur Hangkara & 28 & $14.00 \%$ \\
\hline S2\#27 & Rukun agawe Santosa, crah agawe Bubra & 20 & $10.00 \%$ \\
\hline S1\#54 & Gotong royong lan sepi ing pamrih, rame ing gawe' & 14 & $7.00 \%$ \\
\hline S3\#12 & Ana rembug becik di rembug & 12 & $6.00 \%$ \\
\hline S2\#12 & Tepa selira & 11 & $5.50 \%$ \\
\hline S1\#12 & Budi dayane manungsa ora bisa ngungkuli garise Kang Kuwasa. & 10 & $5.00 \%$ \\
\hline S1\#47 & Hamemayu hayuning bawana & 8 & $4.00 \%$ \\
\hline S1\#37 & Ing ngarso sun tulodo, ing madyo mangun karso, tut wuri handayani & 6 & $3.00 \%$ \\
\hline S2\#25 & Jer basuki mawa bea & 6 & $3.00 \%$ \\
\hline S2\#1 & Andap asor, ajining diri saka ing lathi & 5 & $2.50 \%$ \\
\hline S2\#6 & Rawe-rawe rantas, malang-malang putung & 5 & $2.50 \%$ \\
\hline S2\#13 & Aja dumeh mundhak keweleh & 4 & $2.00 \%$ \\
\hline S1\#18 & Ajining diri dumunung ing kumendaling lathi lan budi', & 4 & $2.00 \%$ \\
\hline S1\#56 & ASUH, ing ngarsa sun tuladha & 4 & $2.00 \%$ \\
\hline S1\#14 & Hyang Widhi iku bisa ngowahi kahanan opo wae tan kena kinaya ngapa. & 4 & $2.00 \%$ \\
\hline S2\#39 & Menang tanpa ngasorake, Nglurug tanpa bala & 4 & $2.00 \%$ \\
\hline & Sugih tanpa banda, sekti tanpa aji-aji, wani perang tanpa bala, menang & & \\
S1\#43 & tanpa ngasorake & 4 & $2.00 \%$ \\
\hline
\end{tabular}


bahasa \& sastra, Vol. 14, No.2, Oktober 2014

\begin{tabular}{|l|l|c|c|} 
S3\#8 & Toto Tentrem Kerto Raharjo & 4 & $2.00 \%$ \\
\hline S1\#21 & Urip manungsa pinasti ing pangeran (Tuhan) & 4 & $2.00 \%$ \\
\hline S1\#48 & Adigang, adigung, Adiguna, & 3 & $1.50 \%$ \\
\hline S2\#9 & Keno iwake ning ojo buthek banyune & 3 & $1.50 \%$ \\
\hline S1\#39 & M enang tanpa ngasorake, Nglurug tanpa bala & 3 & $1.50 \%$ \\
\hline S1\#6 & Akeh bencana tan dinyana-nyana & 2 & $1.00 \%$ \\
\hline S2\#14 & Ana dina, ana upa & 2 & $1.00 \%$ \\
\hline S1\#4 & Aweh rasa resep, pasulayan 'urip tata manungsa' & 2 & $1.00 \%$ \\
\hline S1\#7 & Chakra manggilingan, Jaman iku owah gingsir iku & 2 & $1.00 \%$ \\
\hline S1\#16 & Crah agawe bubrah, rukun agawe santosa & 2 & $1.00 \%$ \\
\hline S1\#3 & Ewoh - pakewoh & 2 & $1.00 \%$ \\
\hline S2\#44 & Menang tanpa ngasorake, Nglurug tanpa bala & 2 & $1.00 \%$ \\
\hline S2\#49 & Ngluruk Tanpa Bala, M enang Tanpa Ngasorake, Sekti Tanpa Aji-Aji, Sugih & & \\
\hline S2\#20 & Ngonpa Bandha & 2 & $1.00 \%$ \\
\hline S1\#29 & Perang iku tanpa guna, lamun asile ora ana; M igunani yen asile ana & 2 & $1.00 \%$ \\
\hline S2\#17 & Tuna sanak, bathi sanak & 2 & $1.00 \%$ \\
\hline S1\#31 & Seje endas, seje penggagas & 2 & $1.00 \%$ \\
\hline & Sepi ing pamrih rame ing gawe, Banter tan M bancangi, Dhuwur tan & 2 & $1.00 \%$ \\
\hline S1\#13 & Ngungkuli, & 2 & $1.00 \%$ \\
\hline S3\#6 & Bhineka Tunggal Eka & 1 & $0.50 \%$ \\
\hline S3\#7 & Gemah ripah loh jinawe, tata, tentrem, kerta, raharja & 1 & $0.50 \%$ \\
\hline S3\#9 & Hyang Widi iku ora mbedak mbedake kawulane & 1 & $0.50 \%$ \\
\hline S3\#2 & Janji iku utang or promise is debt & 1 & $0.50 \%$ \\
\hline S1\#7 & Manunggaling kawula Gusti & 1 & $0.50 \%$ \\
\hline S1\#49 & Ngluruk Tanpa Bala, M enang Tanpa Ngasorake, Sekti Tanpa Aji-Aji, Sugih & 1 & $0.50 \%$ \\
\hline S3\#20 & Ojo dumeh & 1 & $0.50 \%$ \\
\hline S3\#10 & Ojo Rumangsa Bisa, Nanging Bisa Rumongsa, & 200 & $100.00 \%$ \\
\hline & & \\
\hline
\end{tabular}

Discussions on the Underlying Principles of Thought Patterns Manifested in SBY's English Speech Texts.

\begin{tabular}{|l|l|c|c|}
\hline S1\#60 & M emayu Hayuning Bawana, Ambrasta dur Hangkara & 28 & $14.00 \%$ \\
\hline S2\#27 & Rukun agawe Santosa, crah agawe Bubra & 20 & $10.00 \%$ \\
\hline S1\#54 & Gotong royong lan sepi ing pamrih, rame ing gawe' & 14 & $7.00 \%$ \\
\hline S3\#12 & Ana rembug becik di rembug & 12 & $6.00 \%$ \\
\hline S2\#12 & Tepa selira & 11 & $5.50 \%$ \\
\hline
\end{tabular}

After analyzing the underlying principles of thought patterns regarding Javanese philosophy manifested in SBY's English Speech Texts, were founded: 1) Memayu Hayuning Bawana, Ambrasta dur Hangkara (Marwoto, 2008:49) means to show efforts for humans live in the world to pursue safety, happiness and prosperity of the world and its contents in order to keep the world maintained and harmony, as well as the nature of eradicating insolence, and greedy, 14\%, (2) Rukun agawe santosa crah agawe Bubrah, mean to build condition of harmony, world peace, and avoid conflicts, because the conflict can harm both parties, 10\%, (3) Gotong royong lan sepi ing pamrih, rame ing gawe means to work together as multi lateral for reaching 
world peace, 7\%, (4) Ana rembug becik dirembug (Sedyawati, 2003. :24) means: to negotiate all problems can be negotiated because the negotiation can avoid conflict and can achieve cooperation, safe, peaceful and prosperous society, 6\%, (5) Tepa selira means one can not to offend other people's feelings or to ease the burden of others, $5,5 \%$.

\section{CONCLUSIONS}

This Javanese philosophy can support the finding of the SBY's thought patterns change from circular to linear. The underlying principles of SBY's thought patterns manifested in his English Speech Texts. The finding explained that, the underlying principles of SBY's thought patterns relating to Javanese philosophy manifested in his English Speech Texts at the five highest scores level as follow: first is Memayu Hayuning Bawana, Ambrasta dur Hangkara (14\%) means attempt to human's live in the world to have safety, happiness and well-being of the world and its contents, to keep the world maintained and harmony. Second, Rukun agawe santosa crah agawe bubrah (10\%) means he always builds the condition of harmony, world peace, and avoid conflict, because conflict can be detrimental to both parties. Third, Javanese philosophy is tepa selira (7\%). Tepa slira means one can keep the feeling of thinking so as not to offend others or lighten the burdens of others, tolerance; one must have a sense - something felt and experienced by others. Fourth is ana rembug becik dirembug (6\%) means there are negotiations, so all issues can be negotiated because negotiations can avoid conflict and to achieve cooperation, safety, peace and prosperity. The rest of remaining scores are under this level. Based on the review related literature, the findings and conclusions in the previous pages, it is suggested that this research will be useful for teachers of English as some contribution to the study in relation to pragmastylistics, and the addition of this study can provide a good insight about the rhetoric and writing draft of English speech.

\section{ACKNOWLEDGMENTS}

I would like to express my sincere gratitude to journal Bahasa \& Sastra for publishing this article, and the same goes to those who have helped this research.

\section{REFERENCES}

Ary, D. (1979). Introduction to Research in Education. Publisher: Wadsworth.

Berelson, B. (1952 Content Analysis in Communications Research. New York: Free Press.

Benedict, R. (1983). Pattern of Culture. New York: Houghton Mifflin.

Bloomfield, L. (1974). Secondary and Tertiary Responses to Language. London : George Allen \& Unwin.

Bogdan, R.B. and Biklen, S.K. (1996). Qualitative Research for Education: An Introduction to Theory and Methods. Boston: Allyn and Bacon Inc.

Bogdan, R and Taylor, S.J. (1975). Introduction to Qualitative Research Method. New York: Wiley-Interscience.

Chomsky, N. (1972). Language and mind. New York: Harcourt Brace Jovanovich.

Conrad, C. (1989). Strategic Organizational Communication $\left(2^{\text {nd }}\right)$ New York: Holt, Rinehart \& Winston.

D’Angelo, F. J. (1980). Process and Thought in composition. Cambridge : Winsthrop Publishers, Inc.

Djalal, D.P. (2007) The Can Do Leadership, Inspiring Stories from SBY Presidency. REW.

Endraswara, S. (2003). Falsafah Hidup Jawa. Yogyakarta: Cakrawala. 
Guinn, D.M. and Marder, D. (1987). A Spectrum of Rhetoric. Canada: Little, Brown \& Co, Ltd.

Holsti,O.R. (1969). Content Analysis for the Social Sciences and the Humanities. Reading.M.A.: Adison - Wesley.

Kaplan, R. B. (1966). Cultural thought patterns in intercultural education. Language Learning, 16(1), 1-20. [Reprinted in Silva, T., \& Matsuda, P. K. (Eds.). (2001). Landmark essays on ESL writing. Mahwah, NJ: Erlbaum.

Kibrik, A.E. (1977). The Methodology of Field Investigations in Linguistics: Setting up the Problem. Paris: Mouton the Hague.

Krippendroff,K. (1993). Analisis Isi. Jakarta: PT RAJA Grafindo Persada.

Leakey, R. E. (1981). The Making of Mankind. London: Michael Joseph Limited.

Leveridge, A. N. (2008) The Relationship Between Language \& Culture and the Implications for Language Teaching." Sitemap. TEFL.net, Sept. 2008. Web. 31 Jan. 2011.

Malle, L. (2012). Volume 2, Issue 2, November, 2012.

Marwoto, S. (2008). Ramalan Prabu Jayabaya, Yagyakarta : Panji Pustaka.
Miles, M.B. and Huberman A.M. (1992). Qualitative Data Anlysis: An Expanded Source Book. London: Sage Publication.

Ngadiman, A. (1998). Javanese Cultural Thought Patterns as Manifested in Javanese Expository Discourse. Unpublished Dissertation. Malang: IKIP Negeri Malang.

Sedyawati, E. (2003). Budaya Jawa dan Masyarakat Modern. Jakarta: Pusat Pengkajian Kebijakan Teknologi Pengembangan Wilayah BPPT.

Spreadly, J.P. (1980). Participant Observation. USA: Holt, Rinehart and Winston.

Strauss, C. (1997). A Cognitive Theory of Cultural Meaning. Cambridge University Press.

Titscher, S. et al.(2000). Method of Texts and Discourse Analysis. London: Sage Publication Ltd.

Van Dijk, T. A. (1972). Some aspects of text grammars: A study in theoretical linguistics and poetics. The Hague: Mouton. (1985). Handbook of Discourse Analysis. Orlando: Academic Press, Inc. 